\title{
O GÊNERO MEME NO ENSINO MÉDIO TÉCNICO: (RE)CONSTRUÇÕES DE SIGNIFICADOS EM PRODUÇÕES DIGITAIS DE ALUNOS
}

\author{
ROSIVALDO GOMES ${ }^{1}$ \\ HELOANE BAIA NOGUEIRA ${ }^{2}$
}
Universidade Federal do Amapá - Departamento de Letras e Artes
Programa de Pós-graduação em Letras
Rod. Juscelino Kubitschek, km 02 - Jardim Marco Zero, 68903-419
Campus Marco Zero - Macapá, AP - Brasil

$\underline{\text { rosivaldounifap12@gmail.com }, \text { helobaia84@gmail.com }}$

\begin{abstract}
Resumo. Neste artigo, apresentamos a análise da construção de projetos de dizer marcados por intenções discursivas em produções textuais do gênero meme digital, elaboradas por alunos do Ensino Médio Técnico Integrado. $O$ estudo fundamenta-se em discussões sobre letramento digital, nas discussões bakhtinianas sobre gênero do discurso e em aportes conceituais sobre meme. A pesquisa configurou-se como qualitativa interpretativista, tendo sido os dados gerados a partir de uma oficina de produção textual realizada com 12 alunos do IFAP. Com base nos resultados é possível observar que a construção dos projetos de dizer dos participantes configura-se como produções que são estabelecidas a partir de um contexto situado e são carregadas de apreciações valorativas em seus conteúdos temáticos. A análise mostra também que as produções textuais dos textos do gênero meme espelham significações que ultrapassam tanto a situação de produção (momento da oficina) quanto a ideia de que esse gênero serviria somente para despertar o humor.
\end{abstract}

Palavras-chave: meme; produção textual; intenção discursiva.

\begin{abstract}
In this article, we present the analysis of the construction of speech projects marked by discursive intentions in textual productions of the digital meme genre, elaborated by students of Integrated Technical High School. The study is based on discussions about digital literacy, on Bakhtinian discussions about gender discourse and on conceptual contributions about meme. The research was configured as qualitative interpretativist, having been the data generated from a textual production workshop held with 12 IFAP students. Based on the results, it is possible to observe that the construction of the participants' speech projects is configured as productions that are established from a situated context and are loaded with evaluative
\end{abstract}

\footnotetext{
${ }^{1}$ Doutor em Linguística Aplicada pela UNICAMP/IEL e Professor do Departamento de Letras e Artes DPLA/UNIFAP e docente permanente no Programa de Pós-graduação em Letras - PPGLET/UNIFAP.

${ }^{2}$ Mestra em Desenvolvimento Regional pela UNIFAP/PPMD e docente do Curso de Especialização em Linguística Aplicada e Ensino de Línguas - CELAEL/UNIFAP.
} 
appreciations in their thematic contents. The analysis also shows that the textual productions of the meme genre texts mirror meanings that go beyond both the production situation (time of the workshop) and the idea that this genre would only serve to arouse mood.

Keywords: meme; textual production; discursive intention.

\section{INTRODUÇÃO}

Os processos de ensino e de aprendizagem, na contemporaneidade, estão passando por grandes transformações tanto de ordem pedagógica, isto é, sobre o que ensinar e como ensinar, quanto no que diz respeito aos instrumentos ou ferramentas que podem auxiliar na efetivação de tais processos. É no cerne dessas mudanças que estudos realizados no campo da linguagem, especialmente na área de Linguística Aplicada (LA) e no ensino de línguas, têm mostrado como a utilização de tecnologias digitais, recursos e textos multimodais podem contribuir na e para a aprendizagem de línguas (ROJO, 2013; 2019; COSCARELLI, 2016; DIONISIO, 2011; CANI, COSCARELLI, 2016; HEMAIS, 2015, VASCONCELOS, DIONISIO, 2013, GOMES, 2017a).

Assim, inserido no contexto desses estudos, o presente trabalho vincula-se ao projeto de pesquisa ${ }^{3}$ Materiais didáticos digitais e novos (multi)letramentos: caminhos para um web currículo, desenvolvido no âmbito do grupo de estudos Núcleo de Estudos de Pesquisas Interdisciplinares em Linguística Aplicada (NEPLA/CNPq) da Universidade Federal do Amapá. De maneira mais geral, o projeto busca pesquisar o ensino e a aprendizagem de práticas de leitura e de produção textual envolvendo o uso de materiais didáticos e de práticas de letramentos digitais no ensino de Língua Portuguesa com alunos de escolas públicas. Neste texto, trazemos um recorte de alguns dados desse projeto, os quais foram gerados a partir de uma intervenção, no formato de oficina, realizada pelos autores junto ao Instituto Federal de Educação, Ciência e Tecnologia do estado do Amapá (IFAP) ${ }^{4}$, por ocasião da ação de extensão Iférias, realizada nos dias $3 \mathrm{e}$ 4 de julho de 2017.

De acordo com o site do IFAP, o Iférias trata-se de um projeto de extensão com oferta de cursos multidisciplinares de curta duração e atividades culturais diversas, tendo como objetivos estreitar laços com profissionais de outros campi e outras instituições; despertar o senso artístico e cultural dos estudantes e aprimorar a formação escolar/acadêmica destes em suas áreas de desenvolvimento (IFAP, 2017) ${ }^{5}$. Nessa ocasião, houve o convite para que realizássemos uma ação por meio de nosso grupo de pesquisa que pudesse ser ofertada tanto para os alunos do instituto quanto para a comunidade externa.

\footnotetext{
${ }^{3} \mathrm{O}$ referido projeto encontra-se registrado pelo protocolo de $\mathrm{n}^{\circ}$ PVL630-2018, no Departamento de Pesquisa da Universidade Federal do Amapá. Todas as pesquisas a ele vinculadas encontram-se registradas também por meio do mesmo protocolo.

${ }^{4}$ À época de realização da referida intervenção, a primeira autora deste artigo além de pesquisadora do grupo Nepla, também atuava como professora substituta na área de Língua Portuguesa e Literatura nos níveis técnico, básico e superior no referido Instituto.

${ }^{5} \mathrm{Cf}$. site do Instituto.
} 
Desse modo, oferecemos a oficina Remixagem e meme: aprimorando a compreensão do uso de multilinguagens a partir de novos letramentos, cujo objetivo era proporcionar aos participantes práticas de leitura e de produção de textos digitais pelo viés da pedagogia dos multiletramentos (COPE; KALANTIZS, 2000), bem como a análise de exemplares do gênero discursivo meme, sendo considerado para isso aspectos políticos, ideológicos, culturais e multissemióticos desse gênero.

Com a oficina intencionávamos trabalhar práticas de produção textual que possibilitassem aos participantes a compreensão de que nossas intenções discursivas são materializadas em construções textuais a partir de um objetivo discursivo (o que dizer sobre um tema ideologicamente marcado e para que dizer?), em função de um interlocutor em potencial (para quem dizer?), em um contexto sócio-histórico situado (onde? quando?) e em um suporte textual de vinculação (impresso ou digital), sendo que para isso elaboramos um projeto de dizer que envolve, inevitavelmente, segundo Geraldi (1991, 2010) e Koch e Elias (2006), a mobilização de recursos linguísticos para realização desse dizer em um determinado gênero discursivo, o qual é utilizado em práticas reais de uso da língua, sendo ele configurado a partir de um estilo próprio, mas também recebendo marcas do estilo próprio do autor que o produziu, conforme pontua Bakhtin (2003).

Considerando essa perspectiva e os dados gerados a partir da intervenção realizada, buscamos, neste artigo, analisar a construção de projetos de dizer nas produções textuais do gênero meme, as quais foram realizadas pelos participantes da oficina. Para dar conta desse objetivo, buscaremos, ao longo da análise dos dados responder ao seguinte questionamento: como os alunos participantes da oficina se apropriaram de práticas de letramentos digitais e multimodais para construção de seus projetos de dizer considerando tanto aspectos discursivos, multimodais e socioculturais em relação ao gênero meme?

Tendo por base essa questão, com este trabalho buscamos contribuir com dois encaminhamentos importantes para o ensino de Língua Portuguesa a partir das reflexões aqui propostas: i) mostrar a relevância de se considerar as múltiplas linguagens e recursos semióticos de forma reflexiva e crítica no trabalho com o ensino de língua portuguesa e ii) evidenciar como práticas de letramentos digitais podem potencialmente serem usadas na construção de novas formas de aprendizagem e de construção de efeitos de sentidos no trabalho com a produção textual em sala.

Para fundamentação teórica da análise recorremos a discussões que tratam sobre letramento digital (BUZATO, 2006, 2007, XAVIER, 2007, 2011; SAITO; SOUZA, 2011; SELBER, 2004), sobre gênero do discurso (BAKHTIN, 2003) e sobre o gênero meme (LUIZ, 2012; FONTANELLA, 2009; SOUZA, 2013). Os dados analisados foram organizados e categorizados a partir de quadros e das produções de 9 (nove) memes elaborados por 12 alunos do Ensino Médio Técnico do IFAP.

O artigo está dividido em quatro momentos, além desta introdução. No primeiro, apresentamos o referencial teórico utilizado para fundamentar o estudo; em seguida, tratamos do percurso metodológico do estudo e da geração e a análise dos dados; no terceiro momento, apresentamos a análise das produções textuais dos alunos e, por fim, trazemos as considerações finais. 


\section{LETRAMENTOS DIGITAIS: NOVAS PRÁTICAS SOCIOCULTURAIS DE INTERAÇÃO E PRODUÇÃO DE SENTIDOS}

Com o dinamismo que as plataformas digitais oferecem atualmente, a sociedade contemporânea passou a realizar novas práticas de leitura e de produção textual nesses meios, o que ocasionou novos usos da linguagem e novas práticas de letramento (STREET, 1984). Um deles é o que passou a ser denominado de letramento digital, que pode ser entendido, grosso modo, como práticas de leitura e de produções textuais desenvolvidas a partir de tecnologias digitais. Todavia, reduzir a ideia de letramentos digitais apenas às tecnologias digitais é esquecer aspectos socioculturais e impactos ideológicos (BUZATO, 2009) que estão diretamente relacionados com essas práticas.

Nesse sentido, os letramentos digitais devem ser compreendidos a partir de relações socioculturais e como práticas mais amplas que são, assim como outras, ideologicamente marcadas por relações de poder, subjetividade e identidades. Assim, neste artigo, estamos compreendendo os letramentos digitais como "redes complexas e heterogêneas que conectam letramentos (práticas sociais), textos, sujeitos, meios e habilidades que se agenciam, entrelaçam, contestam e modificam mútua e continuamente, por meio, virtude ou influência das TIC" (BUZATO, 2009, p. 22), práticas essas que também envolvem habilidades individuais e sociais necessárias para interpretação, administração, seleção, compartilhamento e produção de novas formas de interação e construção de textos (multimodais ou multimidiáticos), de forma crítica, técnica e ética a partir de meios, dispositivos eletrônicos e recursos digitais (BUZATO, 2006, 2007, XAVIER, 2007, 2011; ARAÚJO, PINHEIRO, 2014).

Conforme propõe Xavier $(2007,2011)$, o letramento digital é mais um tipo e não um novo paradigma de letramento. Esta prática de letramento enxerga os objetos tecnológicos como auxiliadores - não como fins em si mesmos - para produções textuais, podendo também auxiliar em processos de aprendizagens (ROJO, 2007). Ainda sobre esse conceito, Dudeney, Hockly e Pegrum (2016) afirmam que esse tipo de letramento pode ser visto como um conjunto de práticas necessárias para que um indivíduo entenda e use a informação de maneira crítica e estratégica, de várias formas, vinda de múltiplas fontes e apresentada através de diversas mídias.

Dessa maneira, assim como Buzato (2006), compreendemos que os letramentos digitais, por também serem práticas sociais e não variáveis autônomas, tanto afetam as culturas e os contextos nos quais são introduzidos, ou que ajudam a constituir, quanto por eles são afetados, de modo que seus "efeitos" sociais e cognitivos variarão em função dos contextos socioculturais e finalidades envolvidos na sua apropriação (BUZATO, 2006, p. 16).

\section{MEME: UM GENNERO VIRAL DA INTERNET E AS CONSTRUÇÕES MULTIMODAIS DE SENTIDOS}

A expressão meme passa a ser usada nas discussões de Richard Dawkins, em 1976, em seu livro O gene egoísta. Esse autor utilizou o termo como uma metáfora para explicar o processo de evolução da cultura em sociedade. Dawkins (1976) buscou explicar o fenômeno da replicação dos genes como "um meme depende crucialmente da 
quantidade de tempo que algumas pessoas dedicam a transmiti-lo ativamente para outras pessoas" (p. 116). Dawkins definiu, assim, o termo meme para aquilo que podemos repassar de pessoas a pessoas, como comportamento cultural, portanto, um estado de consciência passada de um para outro, mas de forma igual. Aquilo que está armazenado na memória do indivíduo passa a ser repassado dentro de uma comunidade. A partir dessa perspectiva, o temo passou a ser muito utilizado no sentido de replicação no contexto de informações nas redes sociais, sendo denominado, mais recentemente, como meme virtual.

O gênero meme, como o conhecemos hoje, portanto, configura-se a partir de práticas discursivas que objetivam tanto a replicação de alguma informação, seja ela com teor humorístico, crítico, um questionamento, um ponto de vista demarcado, quanto a recriação de sentidos e significações a partir de novos produtos textuais. Nesse sentido, esse gênero configura-se como um discurso que não é autossuficiente (VOLOCHINOV/ BAKHTIN, 1976[1926]), já que ele nasce de uma "situação pragmática extraverbal" e está ligado a práticas de letramentos digitais, pois recria os memes,

são entendidos como artefatos sociolinguísticos-culturais online, os quais podem ser copiados, reeditados e disseminados com propósitos sociais definidos, partindo de suas concepções e características para então, lançar sinais de possibilidades de seu uso nas salas de aula (MACIEL; TAKAKI, 2015, p. 54).

Sobre contexto enunciativo, Volochinov/Bakhtin (1976[1926]) destaca três elementos que compõem a situação extraverbal, os quais são essenciais para a compreensão do sentido de um enunciado como o meme: 1) o horizonte espacial comum dos interlocutores (a unidade do visível), 2) o conhecimento e a compreensão comum da situação por parte dos interlocutores e 3) a avaliação comum dessa situação (VOLOCHINOV/BAKHTIN, 1976[1926], p. 5).

Desse modo, conforme Boa Sorte e Santos (2020), é possível dizer que a produção de um meme parte de uma compreensão responsiva ativa que o produtor tem acerca de algo que está constituído em um determinado contexto e, embora possam parecer textos simplórios, estes demandam habilidades de produção e leitura complexas por parte dos seus autores, tendo em vista que produzir memes significa lidar com um conjunto de recursos visuais e/ou sonoros com intenções primárias que podem gerar diversas outras intenções a depender do conhecimento de mundo de cada pessoa que se depara com essas produções e também da avaliação social que será feita e do conteúdo temático desse gênero.

Nessa mesma linha, Souza (2013, p. 134) propõe que compreendamos os textos mêmicos como construtos textuais que comportam em si mensagens que são "decodificadas pelos cérebros receptores, analisadas, interpretadas, adotadas e, por vezes, replicadas, tal que, ao se familiarizarem com a linguagem contida no componente a ser replicado, estarão dialogando de certa maneira com o criador do meme", sendo que esses textos apresentam, configuram-se estruturalmente a partir de relações verbo-visuais e como um fenômeno social e como prática de atuação interativa. Assim,

[...] coloquialmente os memes são entendidos como ideias, brincadeiras, jogos, piadas ou comportamentos que se espalha através 
de sua replicação de forma viral, e caracterizados pela repetição de um modelo formal básico a partir do qual as pessoas podem produzir diferentes versões do mesmo meme. Dessa forma, os memes se diferenciam dos vídeos virais, pois presumem que, à medida em que o meme se espalhe pela rede, surjam versões alteradas da ideia original. Além disso, quanto às práticas, compreende-se as atividades nas quais as pessoas se envolvem quando interagem com os memes e através delas. Essa é uma forma também de dar conta da agência das pessoas, de sua tentativa de construir subjetividades através dos memes. Os memes se incorporam a práticas culturais já existentes (LIVINGSTONE, 1999, p. 61). Nesse sentido, é preciso contextualizar a sua articulação com os ambientes sociais em que elas se inserem: o espaço privado do lar, o ambiente do trabalho, as diferentes relações sociais estabelecidas entre as pessoas que trocam memes entre si. (FONTANELLA, 2009, p. 9).

Nesse sentido, apoiando-nos também em Marcuschi (2008), para quem os gêneros são plásticos, dinâmicos, podemos dizer que os primeiros memes, denominados de Tirinha Meme, evoluíram a partir de tirinhas e deram origem ao que conhecemos hoje como memes virtuais, originários de interações de usuários de fóruns e blogs com temáticas variadas, como o 4chan e Reddit, conforme salienta Luiz (2012). Nesses espaços, os usuários publicavam postagens anônimas de, literalmente, qualquer tipo de imagem e conteúdo.

Assim, o primeiro meme com um quadro e conhecido como Rage Guy surgiu no ano de 2007, a partir da publicação de um usuário de um fórum que, querendo demonstrar que estava irritado com os demais usuários que buscavam outros sites dedicados ao tema, postou a imagem. Esse primeiro meme deu origem as Rage Comics, que apresentavam ilustrações de expressões humanas grotescas para demonstrações de raiva, fome, decepção, gosto, desejo etc.

De acordo com Luiz (2012), essas primeiras versões possuíam formato de quadrinhos e representavam situações do dia a dia. No ano de 2008, outro usuário publica o Rage Guy em quatro quadros sequenciais, sendo que os três primeiros estavam em branco e o último apresentava uma versão "rabiscada" do personagem gritando "Fffffffuuuuuuuuuuuu". Esse formato foi disponibilizado para que os demais usuários pudessem utilizá-lo para criar outros sentidos e demonstrarem coisas que odiavam. Esse mesmo usuário publicou depois um exemplo por ele produzido, com alguns desenhos e a figura de Rage Guy e sua reação em relação ao ato de defecar:

Figura 1: Figura 1: Modelo básico para meme Rage Guy ${ }^{6}$

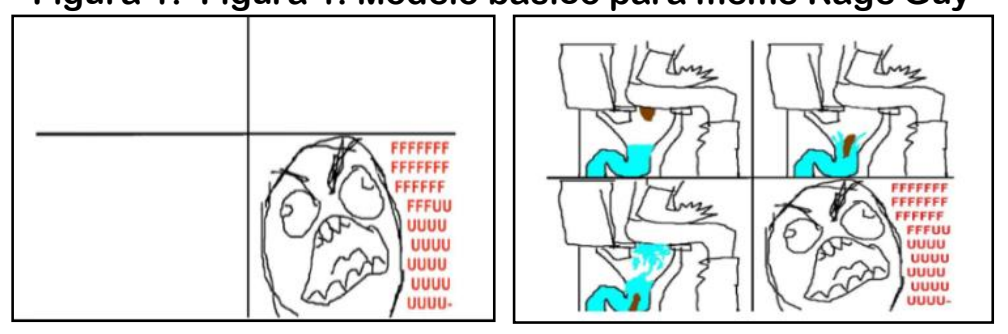

Fonte: www.4chan.org. Acesso em: 4 mar. 2020.

\footnotetext{
${ }^{6}$ Disponível em 4chan (www.4chan.org). Acesso em: 4 mar. 2020.
} 
Com a propagação das Rage Comic nasceram outros sucessos de memes em muitos espaços virtuais, conforme apresentamos no Quadro 2:

\section{Quadro 2: Exemplos de personagens da primeira geração do meme}

\begin{tabular}{|c|c|}
\hline & $\begin{array}{l}\text { LOL Guy: Esse meme no seu início não era um meme e sim uma expressão do } \\
\text { internetês bastante conhecida: LOL (que significa mais ou menos rir alto ou mesmo } \\
\text { rir muito). Com o tempo foi necessário a criação de um personagem para essa } \\
\text { expressão, assim em } 2010 \text { surgiu esse meme, que originou- se de uma expressão da } \\
\text { internet. }\end{array}$ \\
\hline & $\begin{array}{l}\text { Forever Alone: Surgido no Tumblr's, esse desenho ganhou proporções enormes } \\
\text { rapidamente, tornando-se um sinônimo de uma pessoa solitária e também virando } \\
\text { personagem de um grande número de aparições em tirinhas que fazem muito } \\
\text { sucesso. }\end{array}$ \\
\hline & $\begin{array}{l}\text { Troll Face: Atualmente esse é o meme mais famoso na internet, sendo muito } \\
\text { utilizado em tirinhas no mundo todo. O "Troll Face" representa aquele tipo de } \\
\text { pessoa chata que fica estragando algo, criando discussões desnecessárias, } \\
\text { sacaneando ou mesmo "enchendo o saco" de alguém sem motivo. }\end{array}$ \\
\hline & $\begin{array}{l}\text { Fuuuuuu: Esse desenho exprime a ideia de que algo deu errado e que a pessoa } \\
\text { ficou muita brava, furiosa. Daí vem o FUUUUUUUUUU. }\end{array}$ \\
\hline & $\begin{array}{l}\text { Fuck That Guy: Esse meme surgiu em 2009, durante uma entrevista com } \\
\text { jogadores de basquete, onde Yao Ming soltou um sorriso marcante. Depois de ser } \\
\text { filmado nessa entrevista, o vídeo, a imagem dele sorrindo apareceu nas redes } \\
\text { sociais e ganhou o nome de "fuck that", algo que poderia ser traduzido como: Dane- } \\
\text { se isso ou mesmo não estou nem aí ou ainda não me importo. }\end{array}$ \\
\hline & $\begin{array}{l}\text { Me Gusta: O meme "Me gusta" (que quer dizer mais ou menos "eu gosto", em } \\
\text { tradução livre), com o tempo foi ganhando espaço em diversas tirinhas e se tornou } \\
\text { um dos mais famosos memes da internet. }\end{array}$ \\
\hline
\end{tabular}

Fonte: Adaptado de https://pinhaltrollers.wordpress.com/tag/rage-guy/. Acesso em: 4 mar. 2020.

Esses são alguns exemplos de inúmeros memes que foram produzidos na primeira geração, isto é, memes nos quais seus produtores, para representarem e ironizarem situações cotidianas, valiam-se de rabiscos com expressões humanas. Porém, nos últimos anos os memes ganharam uma repercussão estrondosa nas redes sociais, pois sua estrutura - aquela conhecida no formato de tiras (ver figura 1) - modificou-se e passou a ser composta a partir da integração de imagens reais (fotos e figuras) com partes verbais escritas e não mais apenas com rabiscos, conforme figura 2, dando-se início assim à segunda geração de memes: 
Figura 2: Segunda Geração de Memes

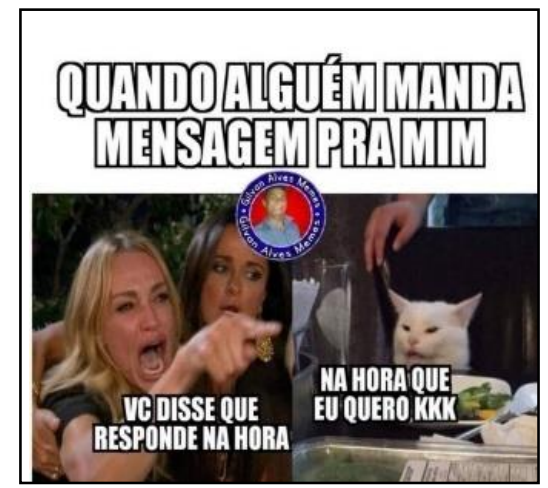

Fonte: https://www.facebook.com/osmemesRm/. Acesso em: 4 mar. 2020.

Em termos bakhtinianos, podemos dizer que o meme configura-se como um enunciado concreto que apresenta uma intenção discursiva a partir de: (a) uma estrutura composicional, caracterizada de forma relativamente padrão, pois costuma ser composto pela semiose/linguagem verbal e visual com imagens/figuras/fotos e, normalmente, envolvendo um bordão, sendo que as imagens não são representações dos textos verbais escritos, mas unidas a essa modalidade de linguagem ajudam na compreensão do objetivo discursivo; (b) um conteúdo temático (e ideológico) que marca uma reação, uma crítica ou humor/entretenimento ou um comentário sobre um acontecimento (de grande impacto ou não), reforçado pela imagem e/ou expressões utilizadas pelo produtor e (c) um estilo de linguagem caracterizado por unidades semióticas e com marcas de registro linguístico da variedade não padrão da língua, apresentando também, às vezes, abreviações. Nesse sentido, o gênero meme configura-se de forma relativamente simples e é marcado por relações multimodais (DIONISIO, 2011; DIONÍSIO; VASCONCELOS, 2013) e por relações de intertextualidade (FIORIN, 2006), que remetem a outras produções textuais instanciadas em práticas comunicativas.

Esse gênero nasce a partir de práticas de letramentos digitais que, atualmente, com a expansão e a evolução de computadores, notebooks, recursos tecnológicos, dispositivos digitais e móveis, têm possibilitado a criação de novas produções textuais. Desse modo, novos textos, que surgiram a partir de práticas de letramentos (digitais conforme já mencionado), passaram a conjugar diversos recursos multimodais, sendo estes textos configurados como o que Dionisio (2011) denominou de textos multimodais, que apresentam duas ou mais formas de representação, ou seja, duas ou mais modalidades de linguagem que auxiliam nos modos de significar (ROJO, 2013) desses textos e que exigem do leitor e do produtor textual práticas de multiletramentos (multissemióticos) habilidades e capacidades de leitura que considerem a conjugação dessas linguagens na produção de sentidos nesses textos.

Assim, com as "novas formas de interação entre leitor e o texto, resultantes da estreita relação entre o discurso e as inovações tecnológicas" (DIONISIO, 2011, p. 139), os textos multimodais podem jogar com variadas situações sociais e diferentes objetivos. Todavia, conforme esclarece Gomes (2017a, p. 85),

[...] embora o caráter multissemiótico dos novos textos/enunciados, marcados pelo hibridismo e/ou intercalação de linguagens/semioses, mídias seja um fator a ser considerado nos efeitos de sentidos nos textos 
de gêneros multissemióticos, não podemos deixar de considerar, também, que esses gêneros são realizados em práticas de linguagem em determinadas práticas de letramentos, e, portanto, são gêneros situados sociocultural e historicamente e pertencente a determinadas esferas/campos ideológicos de comunicação, que possibilitam e dinamizam a existência deles, interferindo diretamente nas formas de produção, circulação e recepção deles.

Além disso, no tocante à leitura e à produção desses textos no contexto escolar, objetivando a atender aquilo que é proposto pelos documentos oficiais, como a BNCC/Brasil (2018), não basta apenas que o aluno (re)conheça as múltiplas linguagens que constituem um texto/enunciado em um determinado gênero. É necessária, também, a compreensão de que as escolhas que o autor faz das linguagens que constituem o gênero e o modo como as integra e as maneja relacionam-se, também, com situações concretas de enunciação onde esse gênero circula, sendo que nisso está implicada uma intenção discursiva e apreciações axiológicas/valorativas que o produtor faz do tema do gênero, da situação de comunicação e dos interlocutores.

\section{METODOLOGIA: CONTEXTO DE GERAÇÃO DOS DADOS E CATEGORIAS DE ANÁLISE}

Este estudo configura-se como qualitativo-interpretativista (MOITA-LOPES, 1994; DENZIN; LINCOLN, 2006), situado no campo da Linguística Aplicada, do tipo documental (GIL, 2008; LANKSHEAR; KNOBEL, 2008). O lócus da realização da oficina que proporcionou a geração dos dados foi o contexto de Educação Profissional Técnico de Nível Médio no Instituto Federal Tecnológico do Amapá (IFAP), localizado na região norte do Brasil. Conforme já dito, a oficina foi desenvolvida no ano de 2017 e na ocasião da realização da oficina, a primeira autora atuava como professora substituta na disciplina de Língua Portuguesa e Literatura.

A oficina realizada teve como objetivo principal propor aos participantes atividades didáticas nas quais foram trabalhadas práticas de letramentos digitais por meio da produção de exemplares do gênero meme, sendo utilizado o software prezi para apresentação de alguns conceitos basilares. O corpus analisado é comporto por 9 (nove) produções textuais de exemplares dos memes, os quais foram produzidos em duplas e em trio pelos participantes. No total participaram da oficina 12 (doze) pessoas, sendo 11 (onze) do instituto, no caso alunos de turmas variadas, e 1 (um) participante externo que fora convidado por um dos alunos.

Para a análise desses dados, consideraremos as categorias descritas no Quadro 3, as quais foram elaboradas a partir das discussões teóricas apresentadas anteriormente: 
Quadro 3: Categorias de análise

\begin{tabular}{|c|c|c|}
\hline \multicolumn{2}{|c|}{ CATEGORIA } & DESCRIÇÃO \\
\hline \multirow{3}{*}{$\begin{array}{c}\text { Projeto de dizer } \\
\text { (Intenção Discursiva) } \\
\text { nas produções dos } \\
\text { memes }\end{array}$} & $\begin{array}{l}\text { Conteúdo Temático } \\
\text { (implicados nesse os } \\
\text { objetivos do dizer) }\end{array}$ & $\begin{array}{l}\text { Criticar, comentar, fazer rir, mostrar } \\
\text { indignação ou espanto; ser um indicador } \\
\text { de opiniões da população; tratar de uma } \\
\text { crítica política ou social ou } \\
\text { comportamento; mostrar ideologias } \\
\text { sociais (evidentes ou não). }\end{array}$ \\
\hline & Forma Composicional & $\begin{array}{l}\text { Multimodal com integração da } \\
\text { modalidade verbal escrita e } \\
\text { visual/imagética, distribuições espaciais } \\
\text { da organização no design visual dos } \\
\text { textos do gênero meme. }\end{array}$ \\
\hline & Estilo & $\begin{array}{l}\text { Recursos linguísticos-semióticos, } \\
\text { referências intertextuais que devem servir } \\
\text { à significação e compreensão dos textos } \\
\text { do gênero meme. }\end{array}$ \\
\hline
\end{tabular}

Fonte: Autoria própria.

\section{A PRODUÇÃO DE MEMES NA OFICINA: (RE)CONSTRUÇÕES DE SIGNIFICADOS EM PRODUÇÕES DIGITAIS DE ALUNOS}

Conforme já mencionado, a geração dos dados partiu de uma oficina desenvolvida com os alunos para a produção dos gêneros memes. Inicialmente, realizamos um diagnóstico oral com os participantes com o objetivo de levantarmos algumas percepções sobre: $\mathrm{O}$ que seria um meme? Por que produzimos memes? Todos servem apenas para entreter, para gerar o humor? Algumas respostas foram sintetizadas no Quadro 4:

Quadro 4: Levantamento diagnóstico feito com os participantes

\begin{tabular}{|c|c|c|}
\hline \multicolumn{3}{|c|}{ PERGUNTAS DIRETIVAS } \\
\hline O que seria um meme? & Por que produzimos memes? & $\begin{array}{c}\text { Todos servem apenas para } \\
\text { entreter, para o humor? }\end{array}$ \\
\hline $\begin{array}{l}\text { São textos usados na internet } \\
\text { Servem para divertir } \\
\text { Às vezes apresentam temas } \\
\text { agressivos } \\
\text { Eles têm imagem e textos } \\
\text { escritos }\end{array}$ & $\begin{array}{l}\text { Para fazer piada } \\
\text { Porque mostra um contexto atual } \\
\text { Para fazer uma crítica, mas de } \\
\text { forma engraçada } \\
\text { Para fazer divertir }\end{array}$ & $\begin{array}{l}\text { A maioria sim } \\
\text { Tem memes que se você não sabe o } \\
\text { contexto não compreende } \\
\text { Alguns servem também para fazer } \\
\text { crítica pelo humor }\end{array}$ \\
\hline
\end{tabular}

Fonte: Dados da pesquisa (2017).

Após as respostas dadas pelos participantes e a realização de algumas discussões sobre o que foi dito, iniciamos a apresentação de alguns conceitos sobre o que seria um meme e como esse termo surgiu. Além disso, tratamos ainda sobre a classificação tipológica desse texto conforme proposta feita por alguns autores, como Recuero (2009), conforme descrição feita no Quadro 5: 
Quadro 5: Descrição dos conceitos trabalhados na oficina

\begin{tabular}{|c|l|}
\hline CONCEITOS TRABALHADOS & \multicolumn{1}{c|}{ DESCRIÇÃO } \\
\hline Definição do gênero meme & $\begin{array}{l}\text { Discussão sobre a origem do termo meme; configuração } \\
\text { como produtos replicadores de aspectos sociais, políticos e } \\
\text { culturais (ideológicos). }\end{array}$ \\
\hline Configuração textual multimodal & $\begin{array}{l}\text { Apresentação da noção de multimodalidade, configuração } \\
\text { multimodal dos memes. }\end{array}$ \\
\hline Tipos de memes & $\begin{array}{l}\text { Classificação tipológica dos memes: Tirinha memes, Rage } \\
\text { Comics, Texto memes; Foto memes; Fidelidade, } \\
\text { Longevidade, Fecundidade, Alcance. }\end{array}$ \\
\hline
\end{tabular}

Fonte: Autoria própria.

A seguir, apresentamos um recorte da apresentação do que foi elaborado na plataforma Prezi no dia da oficina. Na apresentação, trouxemos conceitos iniciais sobre o gênero meme e exemplos, conforme podemos observar nas Figuras 3 e 4:

Figura 3: Conceitos iniciais sobre o gênero meme

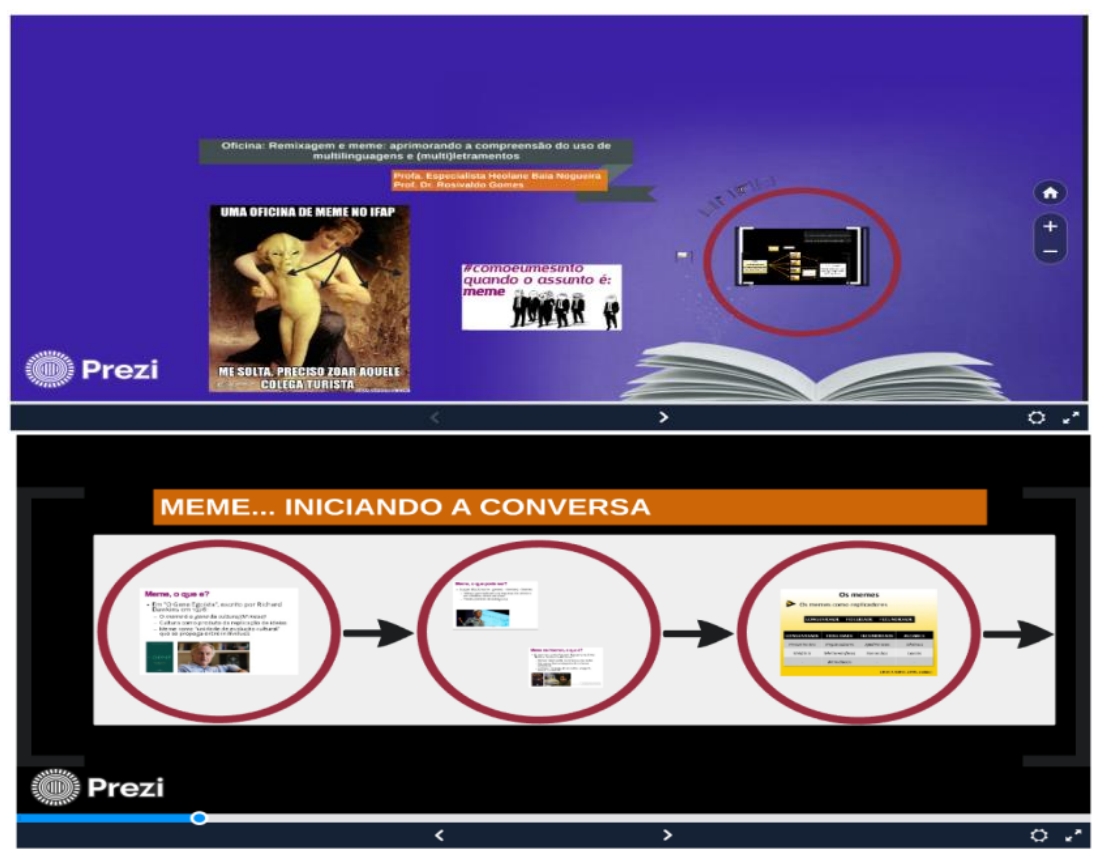

Fonte: Autores (2017).

Figura 4: Detalhamento dos conceitos

Meme, o que è?

- Em "O Gene Egoísta", escrito por Richard Dawkins em 1976:

- O memeé o gene da culturaj(M mese)

- Cultura como produto da replicą̧ăo de ideias - Meme como "unidade de evoluçăa cultural" que se propaga entre individuos
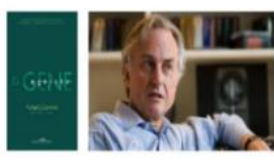

Meme, o que pode ser?

- Susan Blackmore: genes - memes - temes "Ideias que replicam a si mesmas de cérebro Temes (memes tecnológicos)
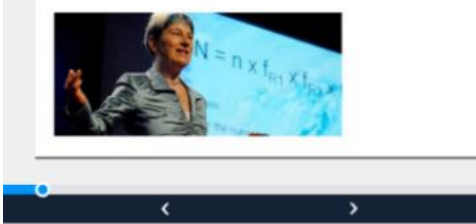

Fonte: Autores (2017).

\section{Meme na internet, o que é?}

- O que nos conta Raquel Recuero no livro "Redes Sociais na Internet":

- Memes fazem parte da dinâmica das redes São uma ordem emergente de sistemas complexos

Exemplo: Propagação de vídeos, imagens, textos na interne
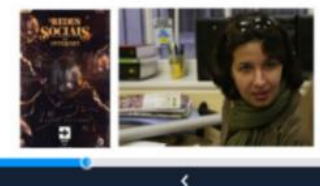
Após a parte teórica apresentada, informamos aos participantes que, atualmente, é possível encontrarmos inúmeros programas e sites que oferecem a possiblidade de criação de memes e, nesse universo de possibilidades, apresentamos a eles o site https://imgflip.com/memegenerator, que apresentava um design de interface de fácil interação e uso. Além disso, o site contém um buscador que se conecta com um banco de imagens e fotos para criação de templetes de memes, contendo personagens brasileiros, estrangeiros (atores de filmes e séries), animais e personagens de desenhos animados. Há ainda a possibilidade de realização de upload de outras imagens para composição de uma galeria e que ficarão armazenadas na conta do usuário, caso ele opte por criar uma.

No lado direito do site, o usuário pode selecionar a imagem ou a foto e, a depender do templete escolhido, pode inserir até três informações verbais escritas que, juntamente com as imagens selecionadas, irão compor a estrutura composicional multimodal do meme que será gerado:

\section{Figura 5: Exemplo de meme feito no site Meme Generator}

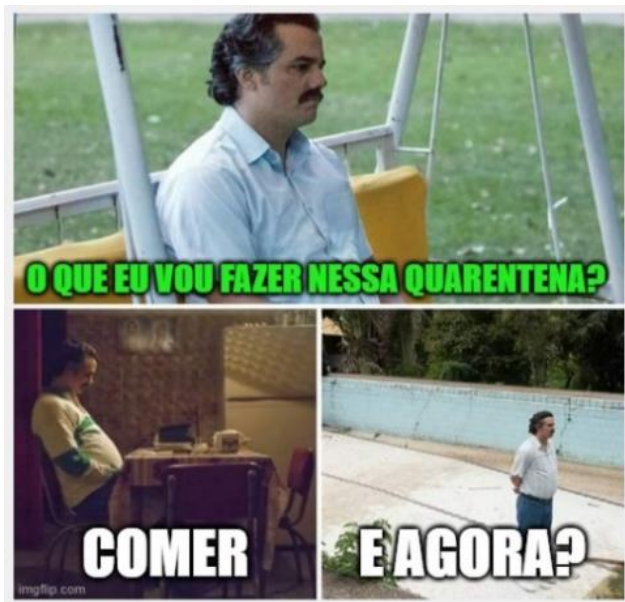

Fonte: https://imgflip.com/memegenerator. Acesso em: 4 mar. 2020.

\section{Figura 6: Tela inicial do site Meme Generator}

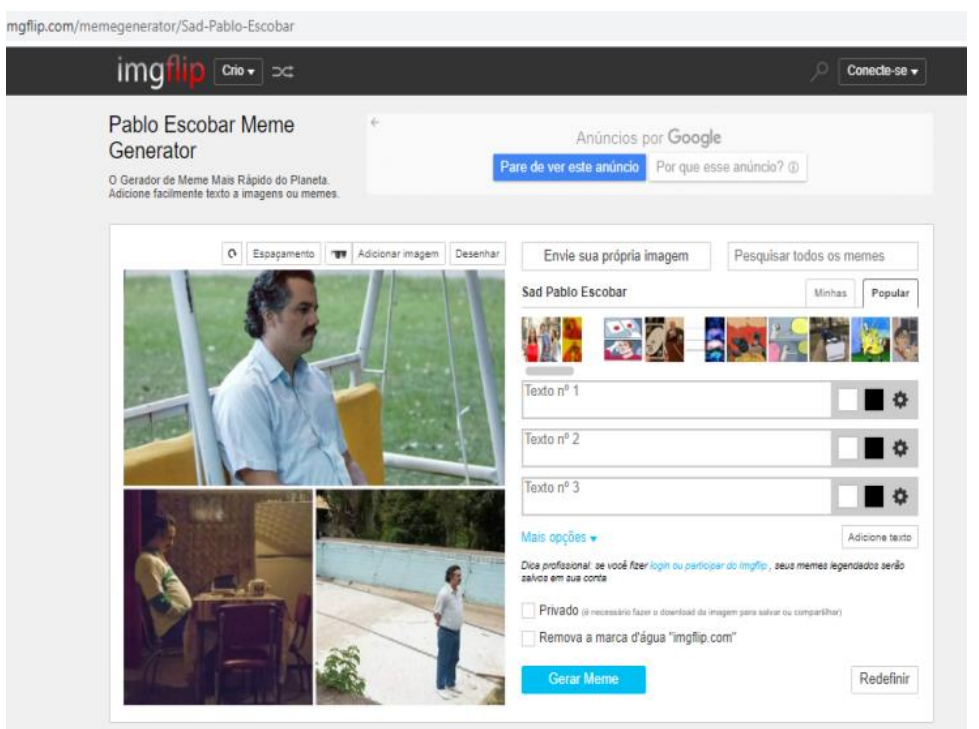

Fonte: https://imgflip.com/i/43brwt. Acesso em: 4 mar. 2020. 
A escolha por um site que não apresentasse muita complexidade para o seu manuseio e que pudesse auxiliar os participantes na produção dos memes foi direcionada a partir da ideia de multiletramentos digitais (SELBER, 2004), uma vez que o foco tanto da oficina quanto das produções não centrava-se em potencializar apenas as práticas de letramentos digitais implicadas no processo de construção desses textos, mas também proporcionar aos participantes a compreensão sobre como essas práticas estão relacionadas com aspectos mais amplos que dão sentidos aos memes, pois esse texto, enquanto produto semiótico, que serve a um agir linguageiro (BRONCKART, 2008), origina-se a partir de contextos sócio-históricos e ideológicos situados.

Assim, após as orientações dadas sobre o funcionamento do site, direcionamos a proposta de produção dos memes, informando aos participantes que não iríamos estabelecer temáticas, mas a integração das imagens com os textos verbais escritos deveria ser contextualizada em função de um fato ou uma questão atual. Desse modo, foram produzidos os 9 (nove) memes, conforme os Quadros 6 e 7:

Quadro 6: Descrição dos memes e das temáticas

\begin{tabular}{|l|l|}
\hline \multicolumn{1}{|c|}{ MEME } & \multicolumn{1}{c|}{ DESCRIÇÃO VERBAL } \\
\hline 1. Do gato sério & "Quando o aluno idiota interrompe a aula" \\
\hline 2. Do gato debochado & "Quando você passa no 3 $3^{a}$ bimestre" \\
\hline 3. Do gato assustado & "Quando vem dois caras numa moto" \\
\hline 4.Personagem de série & "Quando o professor manda colocar o celular em cima da mesa" \\
\hline 5. Crying Meme & "Quando quero ponto extra" \\
\hline 6. Mulher Chorando & "Quando saiu a nota do provão do ifap - "Aí, Misericórdia!!!"” \\
\hline 7. He-Man & "Ñ decorei as fórmulas para a prova, mas minha calculadora tem tampa." \\
\hline 8. Senhora & "A senhora vai ficar até o final da oficina de meme? - Senhora, ainda \\
& não acabou, falta o certificado." \\
\hline 9. O Auto da Compadecida & "- O professor disse q ia lançar a nota no sistema? Você acreditou? \\
\hline
\end{tabular}
Fonte: Autoria própria.

Quadro 7: Configuração multimodal dos memes produzidos

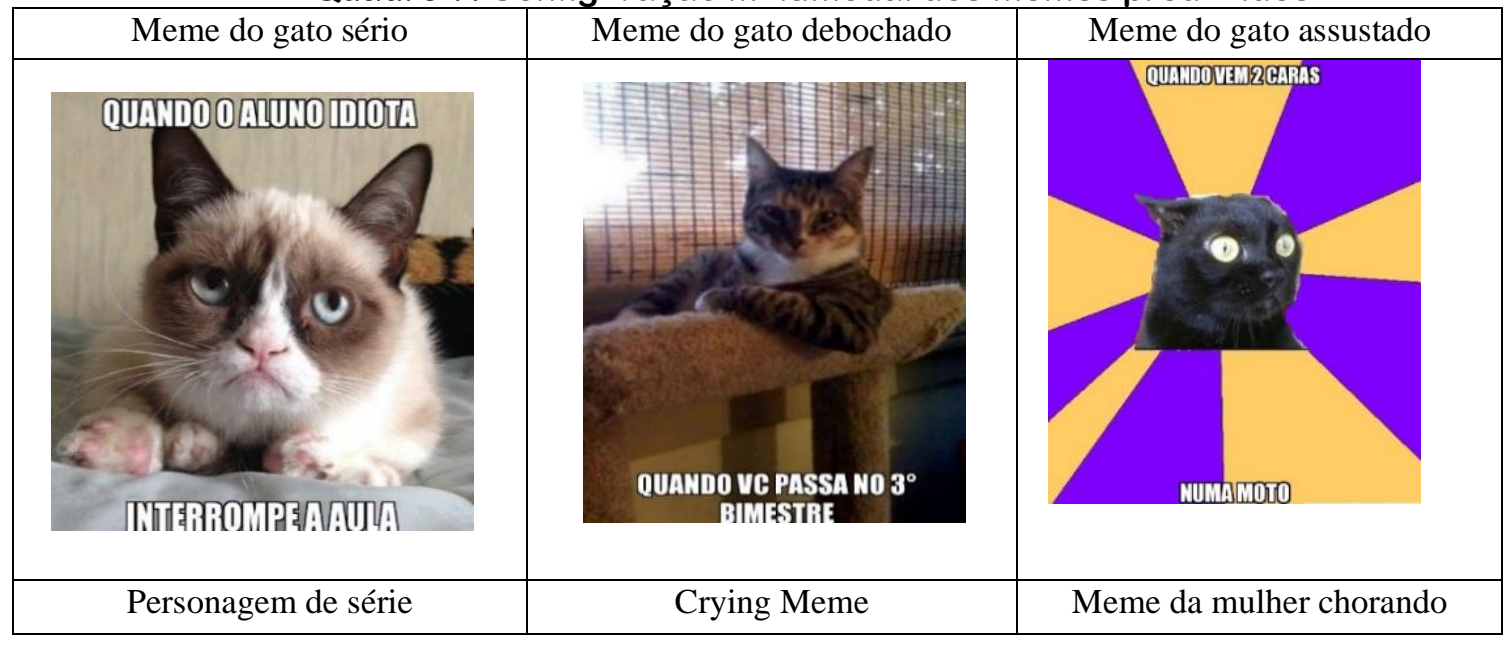




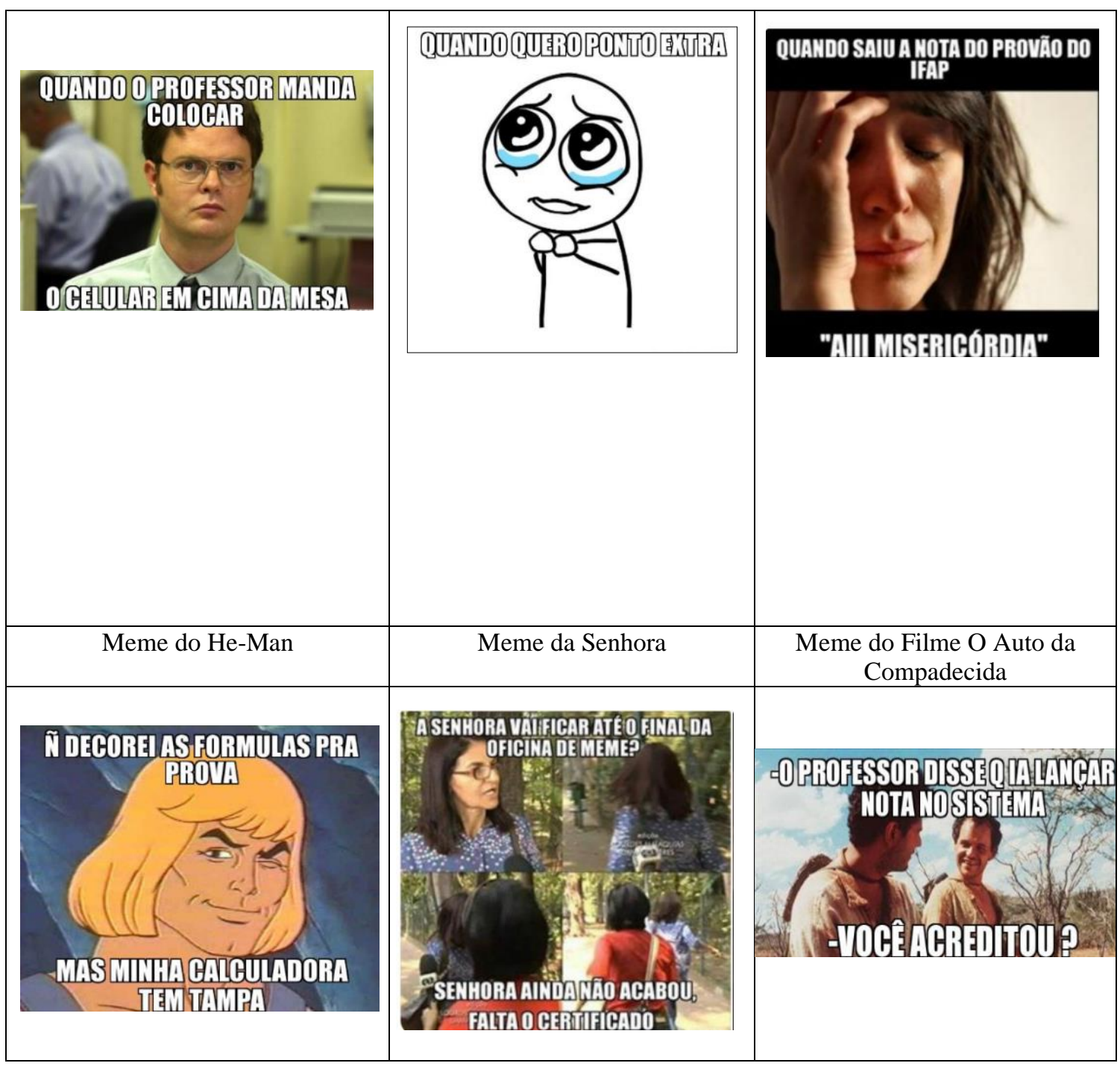

Fonte: Dados de pesquisa do Grupo XXXX.

A partir do conjunto de dados apresentados nos Quadros 6 e 7 é possível observarmos que, em relação aos projetos de dizer (GERALDI, 1991; KOCH, ELIAS, 2006), configurados nas produções textuais dos alunos a partir de suas intenções discursivas, os 9 (nove) textos produzidos, apesar de serem do mesmo gênero discursivo (meme), apresentam conteúdos temáticos (temas) com variações de significações, sendo cada um deles irrepetível (BAKHTIN, 2003). Porém, esses temas, nas intrínsecas relações com práticas sociais, apoiam-se em significações que são estáveis (VOLÓCHINOV, 2017) e marcadas por relações de intertextualidades em suas estruturas composicionais a partir de relações multimodais, uma vez que

[...] o tema do enunciado é tão concreto quanto o momento histórico ao qual ele pertence. $\mathrm{O}$ enunciado só possui um tema ao ser considerado um fenômeno histórico em toda a sua plenitude concreta. É isso que constitui o tema do enunciado [...] juntamente com o tema, ou melhor, dentro dele, o enunciado possui também a significação. Ao contrário do tema, entendemos a significação como aqueles aspectos do enunciado que são repetíveis e idênticos a si mesmos em todas as ocorrências [...] A significação é um artefato técnico de realização do tema. Evidentemente, é impossível traçar um limite absoluto e mecânico entre 
tema e significação. Não há tema sem significação, como não há significação sem tema. Por outro lado, o tema deve apoiar-se em alguma significação estável, caso contrário ele perderá a sua conexão com aquilo que veio antes e que veio depois, ou seja, perderá totalmente seu sentido. (VOLÓCHINOV, 2017, p. 228-229).

Assim, vemos que o meme Do gato sério comporta um conteúdo temático que apoia-se em uma significação direcionada à compreensão de um momento em que um aluno interrompe a aula para fazer algum tipo de "zoeira", mas isso não agrada a todos, sendo isso reforçado a partir da linguagem visual com a imagem de um gato, que aparece em um ângulo frontal e com ar de sério. Já o meme Do gato debochado instancia outro tema, o qual está relacionado à aprovação do aluno com notas boas no $3^{\mathrm{a}}$ bimestre, o que possibilita-o "relaxar" em relação às demais notas ou trabalhos que poderão ainda ser solicitados pelos professores, sendo que para estabelecer essa significação o produtor do texto lança mão, na organização da forma composicional do gênero, da imagem de um gato que, diferentemente do primeiro daquele presente no meme, apresenta-se com uma aparência de descanso e tranquilidade.

O meme Do gato assustado traz em seu conteúdo temático uma significação relativa à possibilidade de assalto. Esse meme também foi replicado (RECUERO, 2009) nas redes sociais com a imagem de seres humanos, especialmente homens. Esse tema está relacionado também com aspectos maiores de enunciações, que direcionam para apreciações valorativas e estereotipadas também sobre a ideia, socialmente propagada de que quem usa moto são pessoas que fazem assalto.

O Crying Meme apresenta um conteúdo temático relativo à necessidade do aluno em obter nota para passar no bimestre; já a Mulher Chorando diz respeito a um conteúdo temático sobre a realização de uma prova de múltipla escolha, a qual é aplicada pelo instituto (Provão), elemento esse avaliativo que deixa muitos alunos apreensivos e, às vezes, desesperados, conforme a imagem da mulher chorando, ao saberem os resultados dessa avaliação. Já os memes He-Man, Senhora e O Auto da Compadecida apresentam conteúdos temáticos relacionados, respectivamente, ao fato de o aluno não ter se preparado para prova, mas tem a "ajuda" da calculadora para soluções das questões; a possibilidade de nem todos os alunos ficarem até o final da oficina de memes, mas lembrarem que o certificado de suas participações nesse evento pode ser útil futuramente e ao não lançamento de notas no sistema de registro escolar do instituto pelos professores.

Na constituição dos temas e das significações desses memes são usados, na composição estrutural desses textos, imagens de personagens como o He-Men, personagem de desenho animado muito utilizado em outros memes, a imagem da servidora pública que foi identificada como funcionária fantasma de um órgão público, de acordo com uma reportagem exibida pela TV Anhanguera em 2015 e uma cena do filme do Alto da Compadecida exibido pela rede Globo.

Cabe destacar, contudo, que os conteúdos temáticos não são o assunto dos textos do gênero meme, pois conforme lembra Fiorin (2006), baseando-se nas discussões bakhtinianas, o conteúdo temático não pode ser compreendido como o assunto, pois o tema abrange um domínio de sentido e seus recortes possíveis para significação de um dado gênero do discurso, daí o fato de que estes configuram-se de forma irrepetível e únicos, sendo também marcados por apreciações volitivas ou avaliações axiológicas 
(VOLÓCHINOV, 2017) que seus produtores fazem de si mesmos, de seus interlocutores, dos lugares sociais por eles ocupados e do contexto tanto de produção quanto de circulação dos gêneros.

É nesse sentido, portanto, que os conteúdos temáticos, figurados nos textos produzidos pelos alunos, não configuram-se de forma aleatória em seus projetos de dizer, já que os temas, por eles mobilizados, fazem parte de situações enunciativas mais amplas, isto é, de contextos extraverbais (VOLOSHINOV/BAKHTIN, 1976[1926]), constituídos por horizontes espacial-temporais específicos, que são compartilhados e considerados na situação concreta de enunciação de produção do gênero meme em cada exemplar analisado, sendo que para materialização verbo-visual desses temas os alunos mobilizam, na configuração da estrutura composicional de seus textos, imagens que são hibridizadas com a linguagem verbal escrita, fazem escolhas lexicais e fraseológicas que remetem ao estilo do gênero meme, mas que também marcam seus estilos próprios como produtores desse gênero e criam, portanto, novas significações.

Além disso, cabe destacar que os objetivos discursivos dos textos produzidos não podem ser direcionados simplesmente no sentido da compreensão que os memes foram elaborados visando apenas causar humor, uma vez que, conforme nos faz lembrar Fairclough (2001), o discurso enquanto prática social não se realiza de forma aleatória, mas sim a partir de ordens discursivas que são instanciadas e, nesse sentido, os textos configuram-se como modos de (re)criação de significados sociais, isto é, modos de agir no e sobre o mundo e sobre as pessoas (significado acional), modos de representar (significado representacional) e modos de ser (significado identificacional).

Sendo assim, os sujeitos exercem papeis de "atores ou agentes sociais" (FAIRCLOUGH, 2003, p. 223) que, discursivamente, marcam suas ideologias nos textos e nesse sentido devemos possibilitar aos alunos o reconhecimento desses modos de manobra da ideologia e introduzi-los em formas arrojadas de letramento é fortalecê-los para que se tornem sujeitos conscientes, críticos, emancipados para uma participação cidadã e, assim, tornarem-se aptos a fazer suas escolhas (ROCHA, 2007).

\section{CONSIDERAÇÕES FINAIS}

A necessidade de se considerar as práticas de letramentos digitais e de letramentos multimodais/multissemióticos tanto no trabalho com a leitura quanto com a produção de textos tem se configurado, no contexto educacional brasileiro, uma necessidade urgente para a formação de sujeitos que sejam capazes não só de consumir novos textos que estão surgindo a partir dessas práticas, mas também que sejam críticos em relação a essas novas produções e que possam também desenvolver capacidades de análise sobre as diferentes formas e manifestações de ideologias marcadas nesses textos vinculados em redes sociais e sites.

Além disso, é mister que os alunos possam também compreender e/ou ampliar a compreensão sobre o funcionamento das tecnologias e recursos digitais para que possam delas se apropriar para melhor participação social em práticas mais amplas de letramentos. Dessa maneira, pela análise dos dados, foi possível observar que a 
construção dos projetos de dizer dos participantes das oficinas não se configura de forma vaga ou fora de sentidos e significações.

Ao contrário, os dados demonstram que as produções textuais dos exemplares dos textos do gênero meme espelham significações que ultrapassam tanto a situação de produção (momento da oficina) quanto a ideia de que esse gênero serve somente para despertar o humor, pois os memes produzidos apresentam conteúdos temáticos variados, situados em instâncias específicas de enunciações e apoiados em significações que são ideologicamente marcadas e que revelam aspectos de comportamentos sociais, fatos e os acontecimentos socioculturais e questões controversas presentes que são delineadas a partir da materialização de relações multimodais, intertextuais e estilísticas nos textos produzidos.

Assim, os memes produzidos são enunciados concretos e marcados por apreciações axiológicas, valorativas-/ideológicas (VOLOCHINOV; BAKHTIN, 1976[1926]; BAKHTIN, 2003), sendo, portanto, gêneros que podem servir às práticas do letramento escolar, pois possibilitam que o aluno questione, problematize e discirna, a partir de uma postura crítica e de uma compressão responsiva ativa dos conteúdos temáticos presentes nesse gênero (JORDÃO, 2016; JANKS, 2016; BAKHTIN, 2003), questões que negam, silenciam ou colocam em evidência certos discursos hegemônicos.

\section{REFERÊNCIAS}

ARAÚJO, J.C.; PINHEIRO, R. C. Letramento digital: história, concepção e pesquisa. In: GONÇALVES, A. V.; et. al. (org.). Visibilizar a Linguística Aplicada: abordagens teóricas e metodológicas. Ed. Campinas: Pontes Editores, 2014. p. 293-320.

BAKHTIN, M. Estética da criação verbal. 4. ed. Tradução de Paulo Bezerra. São Paulo: Martins Fontes, 2003.

BAKHTIN, M. Os gêneros do discurso. In: BAKHTIN, M. Estética da criação verbal. São Paulo: Martins Fontes, 2003. p. 261-30.

BOA SORTE, P., SANTOS, C. A. J. Memes em aulas de língua inglesa. Revista I, Natal, v. 58, n. 55, p. 1-19, 2020. Disponível em: https://periodicos.ufrn.br/educacaoemquestao/article/view/18439/12478. Acesso em: 08/05/2020.

BRASIL. Base Nacional Comum Curricular: Ensino Médio. Brasília: MEC/Secretaria de Educação Básica, 2018. Disponível em: $<$ http://basenacionalcomum.mec.gov.br/images/BNCC_EI_EF_110518_versaofinal_site .pdf>. Acesso em: 08/05/2020.

BRONCKART, J.P. Atividade de linguagem, discurso e desenvolvimento humano. Tradução de Anna Rachel Machado, Maria de Lourdes Meirelles Matencio. Campinas. São Paulo: Mercado das Letras, 2006.

BUZATO, M. E. K. Entre a fronteira e a periferia: linguagem e letramento na inclusão digital. 2007. 284 f. Tese (Doutorado) - Instituto de Estudos da Linguagem, Universidade Estadual de Campinas, Campinas, São Paulo, 2007.

BUZATO, M. E. K. Letramento e Inclusão na Era da Linguagem Digital. Editora: Mimeo. IEL/UNICAMP, Março de 2006.

BUZATO, M. E. K. Tecnologia, espaço temporalidade e educação: Contribuições dos estudos sobre Novos Letramentos para uma reflexão sobre EAD e Universidade no Brasil. 
II Seminário de Educação à Distância da Faculdade de Educação. Campinas, 2009c. p. 1-23.

COPE, B. KALANTZIS, M. (Eds.) Multiliteracies: Literacy Learning and the Design of Social Futures. Routlege: London, 2000.

COSCARELLI, C. V. CANI, J. B. et al.. Textos multimodais como objetos de ensino: reflexões em propostas didáticas. In: KERSCH, D.F; COSCARELLI, C.V.; CANI, J. B. (org.). Multiletramentos e multimodalidade: ações pedagógicas aplicadas à linguagem. Campinas, São Paulo: Pontes Editores, 2016. p. 15-48.

COSCARELLI, C.V. (org.). Tecnologias para aprender. São Paulo: Parábola Editorial, 2016.

DAWKINS, R. O gene egoísta. São Paulo: Companhia das Letras, 2007.

DENZIN, N.; LINCOLN, Y. A disciplina e a prática da pesquisa qualitativa. In: DENZIN, N.; LINCOLN, Y. O Planejamento da pesquisa qualitativa: teorias e abordagens. Porto Alegre: ArtMed, 2006. p.15-41.

DIONISIO, A. P. Gêneros multimodais e multiletramentos. In: KARWOSKI, A.M.; GAYDESZKA, B.; BRITO, K. Siebeneicher. (org.). Gêneros textuais: reflexões e ensino. Palmas e União Vitória, PR: Kaygangue, 2005. p. 137-152.

DIONISIO, A. P.; VASCONCELOS, L. J. de. Multimodalidade, gênero textual e leitura. In. BUNZEN, C; MENDONÇA, M.(org.). Múltiplas linguagens para o ensino médio. São Paulo: Parábola, 2013. p. 19-42.

DUDENEY, G.; HOCKLY, N.; PEGRUM, M. Letramentos digitais. Tradução de Marcos Marcionilo. São Paulo: Parábola Editorial, 2016.

FAIRCLOUGH, N. Analysing discourse: Textual analysis for social research. London: Routledge, 2003.

FAIRCLOUGH, N. Discurso e mudança social. Brasília: Editora Universidade de Brasília. 2001.

FIORIN, J. L. Interdiscursividade e intertextualidade. In: BRAIT, B. (org.). Bakhtin: outros conceitos chave. São Paulo: Contexto, 2006. p. 161-193.

FONTANELLA, F. O que é um meme?: proposta para uma problemática da memesfera. In: SIMPÓSIO NACIONAL ABCIBER, 3, ESPM, São Paulo, 16-18 de novembro de 2009. Anais. São Paulo: ESPM, 2009.

GERALDI, J. W. Ler e escrever na escola e fora dela. In: GERALDI, J. W. A aula como acontecimento. São Carlos: Pedro \& João Editores, 2010. p. 139-147.

GERALDI, J. W. Portos de passagem. São Paulo: Martins Fontes, 1991.

GIL, A. C. Como elaborar projetos de pesquisa. 4. ed. São Paulo: Atlas, 2008.

GOMES, R. Leitura de gêneros multissemióticos e multiletramentos em materiais didáticos impressos e digitais de língua portuguesa do ensino médio. 2017, 260p. Tese (Doutorado em Linguística Aplicada). Instituto de Estudos da Linguagem, Universidade Estadual de Campinas, Campinas, 2017.

HEMAIS, B. J. W. (org.) Gêneros discursivos e multimodalidade: desafios, reflexões e propostas no ensino de inglês. Campinas, São Paulo: Pontes, 2015.

JANKS, H. Panorama sobre letramento crítico. In: JESUS, D. M.; CARBONIERI, D. (org.). Práticas de multiletramentos e letramento crítico: outros sentidos para a sala de aula de línguas. Campinas, São Paulo: Pontes, 2016, p. 21-39.

JORDÃO, C. M. No tabuleiro da professora tem... Letramento crítico? In: JESUS, D. M. de.; CARBONIERI, D. (org). Práticas de Multiletramentos e Letramento Crítico: outros sentidos para a sala de aula de línguas. Coleção Novas Perspectivas em Linguística Aplicada, v. 47. Campinas, São Paulo: Pontes Editores, 2016. p. 41-53. 
KOCH, I. V.; ELIAS, V. M. Ler e Compreender os sentidos do texto. São Paulo: Contexto, 2006.

LANKSHEAR, C.; KNOBEL, M. Panorama da coleta de dados na pesquisa qualitativa. In: Pesquisa pedagógica: do projeto à implementação. Porto Alegre: Artmed, 2008. p.149-166.

LUIZ, L. Fffffffuuuuuuuuuuuu: o fenômeno das rage comics e sua relação com os quadrinhos. In: XXXV Congresso Brasileiro de Ciências da Comunicação, Fortaleza, 2012.

MACIEL, R. F.; TAKAKI, N. H. Novos letramentos pelos memes: muito além do ensino de línguas. In: MACIEL, R. F.; JESUS, D. M. (org.). Olhares sobre tecnologias digitais: linguagens, ensino, formação e prática docente. Campinas: Pontes, 2015. p. 53-82.

MARCUSCHI, L. A Produção textual, análise de gêneros e compreensão. São Paulo: Cortez, 2008.

MOITA LOPES, L.P. Pesquisa Interpretativista em Linguística Aplicada: a linguagem como condição e solução. In: DELTA, Vol 10, n², 1994. p. 329-338.

MOITA LOPES, P. Identidades fragmentadas: a construção de raça, gênero e sexualidade na sala de aula. Campinas, São Paulo: Mercado de Letras, 2002.

RECUERO, R. C. Memes em weblogs: proposta de uma taxonomia. Conexões nas Redes Midiáticas. Revista FAMECOS, Porto Alegre, n. 32, p. 23-31, abr. 2007.

ROCHA, C. H. O ensino de línguas para crianças no contexto educacional brasileiro: breves reflexões e possíveis provisões. DELTA, Vol.23, n.2, 2007. p.273-319.

ROJO, R. H. R. (org.). Escola conectada: os multiletramentos e as TICs. São Paulo: Parábola,2013.

ROJO, R. H. R. Entre Plataformas, ODAs e Protótipos: Novos multiletramentos em tempos de WEB2. THE ESPECIALIST, v. 38, p. 1-20, 2017.

ROJO, R. H. R. Letramentos digitais - a leitura como réplica ativa. Trabalhos em Linguística Aplicada (UNICAMP), v. 46(2), p. 63-78, 2007.

ROJO, R. H. R.; MOURA, E. Letramentos, Mídias, Linguagens. São Paulo, São Paulo: Parábola Editorial, 2019.

SELBER, S. A. Multiliteracies for a Digital Age. Carbondale: Southern Illinois University Press, 2004.

SOUZA, C. F. Memes: formações discursivas que ecoam no ciberespaço. VÉRTICES, Campos dos Goytacazes/ RJ, v.15, n. 1, p. 127-148, jan./abr. 2013.

STREET, B.V. Literacy in theory and practice. Cambridge: CUP, 1984.

VOLÓCHINOV, V. (Círculo de Bakhtin). Marxismo e filosofia da linguagem. Problemas fundamentais do método sociológico na ciência da linguagem. Tradução, notas e glossário de Sheila Grillo e Ekaterina Vólkova Américo. Ensaio introdutório de Sheila Grillo. São Paulo, São Paulo: Editora 34, 2017, 373p.

VOLOSHINOV, V. N.; BAKHTIN, M. M. Discurso na vida e Discurso na arte (Sobre poética sociológica). Tradução para o português feita por Carlos Alberto Faraco e Cristovão Tezza, para uso didático, feita a partir da tradução inglesa de I. R. Titunik (Discourse in life and discourse in art - concerning sociological poetics), publicada em V. N. Voloshinov, Freudism, New York. Academic Press, 1976 (s/d [1926]).

XAVIER, A. C. Letramento digital: impacto das tecnologias na aprendizagem da Geração Y. Calidoscópio, São Leopoldo, v. 9, n. 1, p. 3-14, jan./abr. 2011.

XAVIER, A. C. S. Letramento digital e ensino. In: SANTOS, C. F.; MENDONÇA, M. (Org.). Alfabetização e letramento: conceitos e relações. Belo Horizonte: [Autêntica]; 2007. 
Artigo recebido em: jun. de 2020.

Aprovado e revisado em: out. de 2020.

Publicado em: dez. de 2020.

Para citar este texto:

GOMES, Rosivaldo; NOGUEIRA, Heloane Baia. O Gênero Meme no Ensino Médio Técnico: (re)construções de significados em produções digitais de alunos. Entremeios [Revista de Estudos do Discurso, ISSN 2179-3514, on-line, www.entremeios.inf.br], Seção Estudos, Programa de Pós-Graduação em Ciências da Linguagem (PPGCL), Universidade do Vale do Sapucaí (UNIVÁS), Pouso Alegre (MG), vol. 22, p. 134-153, jul. - dez. 2020.

DOI: http://dx.doi.org/10.20337/ISSN2179-3514revistaENTREMEIOSvol22pagina134a153 